\title{
Peertechz
}

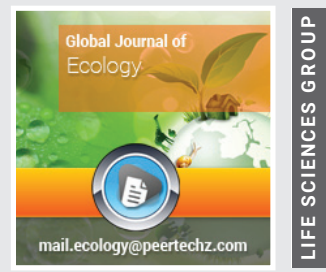

\section{Despite various initiatives thus far can there be sustainable development for humanity?}

\section{Dokun Oyeshola*}

Department of International Relations, Faculty of Administration, Obafemi Awolowo University, Ile-Ife, Osun State, Nigeria

Received: 22 July, 2020

Accepted: 21 September, 2020

Published: 22 September, 2020

*Corresponding author: Dokun Oyeshola, Professor, Department of International Relations, Faculty of Administration, Obafemi Awolowo University, Ile-Ife, Osun State, Nigeria, Tel: +2348034736810; E-mail: doyeshola@oauife.edu.ng, oyesholadokun@gmail.com

Keywords: Sustainable development; Ideology; Sustainable development paradigm; Principles of sustainable development; Environmental law Environmental protection and remediation

https://www. peertechz.com

Check for updates

\section{Abstract}

There are varieties of efforts to arrest the challenges of environmental degradation and promote sustainable development at the domestic and global levels. These efforts are carried out within the context of international politics with its core values of national interest ideology, democracy and liberalism. The outcome of the efforts is still very far from the objectives and goals of sustainable development judging from the global reality where some human activities are still contributing immensely to the polluted land, air and water leading to climate change and consequent challenges to the carrying capacity of the Planet. Within the international system, it has been observed that there are two major arbitrary systems that are vying for control of the world. These are the soft totalitarianism of secularism and the hard totalitarianism of Islam. It is in this light of the above observations that I am particularly interested in asking the question that despite various initiatives on ground thus far and the ones to be designed, can there be sustainable development for humanity?.

\section{Abbreviations}

ARISP: Academics, Research, Innovation and Strategic Partnerships; DAC: Development Assistance Committee; EGASPIN: Environmental Guidelines and Standards for the Petroleum Industry in Nigeria; EIA: Environmental Impact Assessment; ICSU: International Council of Scientific Unions; IMF: International Monetary Fund; ISC: International Social Council; IUCN: International Union for Conservation of Nature and Natural Resources; MAI: Multilateral Agreement on Investment; MDGs: Millennium Development Goals; NESREA: National Environmental Standards and Regulations Enforcement Agency; NIMASA: Nigerian Maritime Administration and Safety Agency; NNPC: Nigerian National Petroleum Corporation; NOSRA: National Oil Spill Detection and Response Agency; NPA: Nigerian Ports Authority; OECD: Organization for Economic Co-operation and Development; ONWA: Oil in Navigable Waters Act; RMAFC: Revenue Mobilization Allocation and Fiscal Commission; SALWs: Small Arms and Light weapons; SDGs: Sustainable Development Goals; UNCED: United Nations Conference on Environment and Development; UNCHE: United Nations Conference on Human Environment; UNDP: United Nations Development Programme; UNEP: United Nations Environmental Programme; UNFCCC:
United Nations Framework Convention on Climate Change; WCED: World Commission on Environment and Development; WTO: World Trade Organization

\section{Introduction}

Several efforts have been made to bring about sustainable development to international community. Some of the conferences of the 1990s in this respect include the Beijing Summit on Gender and the Cairo Conference on Population and Development. The resolutions of those conferences were first codified by the Development Assistance Committee (DAC) at the Organization for Economic Co-operation and Development (OECD) in 1995. Earth summits of 1972 and 1992 are part of the effort to address sustainable development.

In September 2000, world political leaders/head of governments converged at the United Nations Headquarters in New York for United Nations General Assembly and adopted the United Nations Millennium Development Goals (MDGs) which introduced a new partnership for international cooperation against new waves of contemporary global challenges sustainable development inclusive.

The Declaration was adopted as a global vision for the 
future (http://www.un.org/millennium/declaration/ares552e. htm). It was based on a set of fundamental rights of freedom, equity, solidarity, tolerance, respect for nature and shared responsibility and structured according to the subjects of peace, security and disarmament; development and poverty eradication; protecting common environment; human rights, democracy and good governance; protecting the vulnerable; meeting the special needs of Africa and strengthening the United Nations.

The MDGs of 2000 was instituted to radically bring about development to the developing countries by the year 2015. The verdict on the project by the year 2016 was not an overwhelming success. Therefore. it may be argued that the emergence of the Sustainable Development Goals (SDGs) is an indictment that the MDGs had failed in its development objectives although in some quarters, SDGs just succeeded the MDGs. The year of reckoning of SDGs when its objectives will be subjected to a critical evaluation is 2030 .

Ironically, the Conference 'Achieving Sustainable Development in the Least Developed Countries - Towards LDC-V' to hold towards the end of 2020 in Finland is calling attention on the development challenges of the LDGs. Some of its objectives include

a. Solicit new thinking on the challenges and policy recommendation for LDCs for the next decade;

b. Address the structural challenges and emerging issues LDCs face in pursuing sustainable development;

c. Identify policy recommendations which will significantly impact the LDCs to the extent they can meet the SDGs, effectively compete the global economy and move towards convergence with other more developed economies.

Meanwhile the activities and programmes of SDGs are still on going and verdict on it still has about ten years to come. Does this mean that faith in the SDGs is already lost? This is problematic. It is in this light that I am particularly interested in asking the question that despite various initiatives on ground thus far and the ones to be designed, can there be sustainable development for humanity? The outline of this paper will cover the Introduction, constituent elements of sustainable development, sustainable development paradigm, reality on ground and recommendation.

\section{Constituent elements of sustainable development}

The constituent elements of sustainable development include the following namely good quality of human life of all, living within the carrying capacity of the planet, supporting ecosystems, a new way of living devoid of extravagancy and wastage, a new way of approaching social and economic activities of all societies that is compatible with the preservation of the environment - \{'Economics is always an instrumental science; it does not deliberate about ends but only about the means to an end, namely, the satisfaction of wants and desires, whatever they may be. It eschews moral arguments about what is intrinsically or objectively better or worse, right or wrong. It does not talk about the beauty of nature, for example, but about the "amenity" benefits for which individuals are willing to pay. Economics does not conjecture on the nature of the good life but leaves every person to be the judge of his or her own welfare' (Mark Sagoff in Dallmeyer and Ike (eds), 1998: 31)\} -, development practice that meets the needs of the present and future generations, a way of bringing together the ecological, economic and social aspects of a problem, a holistic approach to things inclusive of ethics.

If it is presumed from the above descriptions that the resources of the planet earth are finite and exhaustible then they must be used judiciously and ecological policies and legislations must serve the public interest and the common good of all. Such policies and programmes must go beyond the personal, ethnic, national interests of present generation and look forward to the interest of future generations as well. Earthquake, erosion, desertification, deforestation, etc (environmental degradation) and climate change that are threatening global landscape must be aggressively confronted. In this context unrelenting pursuit of sustainable ecology becomes mandatory for everybody.

However, it may be observed that historical background and legacy of domination received no serious attention and by implication the partial causes of the problematic in Africa - for instance infrastructural deficit, climate change, natural disasters, environmental degradation, mismanagement of natural resources, urbanization, unequal trade agreement between the North and the South and so on - have not been radically interrogated.

\section{Sustainable development paradigm}

\section{General principles of sustainable development}

Four principles are mentioned here. They are

a) Preventive principle requires that activity which does or will cause environmental pollution or damage is to be prohibited.

b) Precautionary Principle. In its most progressive formulation, the principle may be utilised to overturn the traditional burden of proof that is presently weighted in favour of polluters in the sense that any activity has to be proven to cause pollution before action may be taken to prevent, reduce or control such pollution. The precautionary principle would act to reverse the burden of proof and require any potential polluter to ensure that the activity would not cause pollution before it is allowed to commence.

c) The third principle is polluter pays. This principle provides that the cost of environmental pollution should be borne by those whose activities are responsible for causing pollution.

d) The principle of citizen participation and the right to a healthy environment is based on the premise that to ensure the effective implementation of environmental 
laws at all levels, individuals should be able to participate in environmental decision-making.

\section{International environmental law principles}

a) Sustainable Development Is the first international environmental law principle that states that conservation of natural resources for the benefit of the present and future generations (inter-generational equity) must be sustained while the exploitation of natural resources must be 'sustainable' or' prudent' (sustainable use). There is 'equitable use' of natural resources which implies that the use by one state must take account of the needs of other states (equitable use, or intra-generational equity). Further elements of sustainable principle include integration of environmental considerations into socio-economic and development plans, programmes and projects (integration of environment and development needs) $[1,2]$. All these elements, later in 2002, in Johannesburg, South Africa, became the articles of the Conference.

Through Decleries [3] the following international law principles have seen the light of day.

\section{b) Principle of Public Environmental Order}

That all members of the society, the administration, groups, organizations, businesses and citizens are called upon to collaborate in sustainable development but under the strategic control and supervision of the state (i..e. Government).

\section{c) Principle of Carrying Capacity}

In its narrow scientific meaning, carrying capacity is the number of species or units or species which can be maintained indefinitely by an ecosystem without degradation of that system. Is our ecosystem not being stressed beyond its carrying papacy as a result of human population, climate change, flamboyant life style of some people and environmental degradation?

d) Principle of Obligatory Restoration of Disturbed Ecosystem

Sustainable development, understood as the balanced coevolution of the human-made system and ecosystems, has become obligatory in Law when that balance had already been seriously disturbed to the detriment of the ecosystems. Forests have been burned or cleared, wetlands have been drained, coasts and seas have been polluted. Consequently, in today's world, it is an exercise in futility to strive for balance between human-made systems and ecosystems except correspondingly, abrupt stride is taken to restore the destroyed ecosystems.

\section{e) Principle of Biodiversity}

The principle of biodiversity recognizes the inherent value of wild flora and fauna species, and provides legal protection, for all the variety of these species and for their habitats. The intrinsic value of species is in particular that they are biogenetic reserves and constitutes an integral part of the ecosystems. In that sense, biodiversity is protected as the pre-eminent principle of the stability and vigour of ecosystems, according to the reasoning that the greater an ecosystems' biodiversity, the greater is its stability.

\section{Municipal Legislative and Institutional Framework of Environmental Protection and Remediation of Nation States.}

Every nation state has put in place some of the Legislative and Institutional Framework of Environmental Protection and Remediation. Here, the example of a list in Nigeria is illustrative.

\section{Criminal Code Acts}

Oil in Navigable Waters (ONWA) Act

The Oil in Navigable Waters Act

National Oil Spill Detection and Response Agency (NOSDRA)

National Environmental Standards and Regulations Enforcement Agency (Establishment) (NESREA) Act 2007.

Environmental Guidelines and Standards for the Petroleum Industry in Nigeria (EGASPIN)

Nigerian Meteorological Agency (NIMET) (Establishment, etc.) Act

National Oil Spill Detection and Response Agency (NOSDRA)

Nigerian Meteorological Agency (NIMET) (Establishment, etc) Act

National Environmental Standards and Regulations Enforcement Agency (Establishment) (NESREA) Act 2007.

Petroleum (Drilling and Production) Regulations, 1969

Nigerian Meteorological Agency (NIMET) (Establishment, etc.) Act

Associated Gas Re-Injection Act (1979)

Nigerian Maritime Administration and Safety Agency (NIMASA)

Ni4gerian National Petroleum Corporation (NNPC)

Nigerian Security and Civil Defense Corps (NSCDC) Act

Harmful Waste (Special Criminal Provisions) Act Cap. 165 LFN Now Cap. HIFN 2004

Environmental Impact Assessment Act

[For a comprehensive review of the legislative and institutional framework see [4].

\section{The reality on ground and recommendation}

International system where world politics finds a home has come to stay and every country in the globe is an integral part. Therefore, finding solutions to the challenges of the world 
must necessarily be local, national, international and corporate in nature, and challenges of sustainable development in global context are central.

The Planet is a common heritage to all living beings and whatever happens to it will affect its constituent parts. By the way of finding solutions to the challenges of sustainable development the South alleged that the West was primarily responsible for global warming while the industrialized countries of the North would pass the blame to the developing countries (Stockholm and Rio Conferences). The truth of the matter is that there is no sector of the global community that has not contributed to the problems of environmental abuse because all contribute to the emission of greenhouse gases that are principally responsible for climate change though not necessarily equally. Flamboyant life style and unsustainable socio-economic practices of all rich persons both in the North and the South contribute to climate change.

In the past, international politics of dominant national interest ideology was tolerated when the issues of security (understood in military terms) and economic growth were considered the problems of the time. Today, technological advancement, globalization and the threat of climate change have altered the contemporary global scenario. Necessity for a paradigm shift has emerged because the issue of the death of the planet and survival of all is implicated. The paradigm shift that is called for is a collaborative approach to the environmental challenges with common good of the international community as the focus. Unfortunately, national interest ideology is very much at the core of both the domestic and foreign policy agenda of nation states.

Arguably, some human activities have contributed immensely to the polluted land, air and water leading to climate change and consequent challenges to the carrying capacity of the Planet. Polluting activities of human are primarily anchored on the national interest ideology phenomenon and violation of the first principle of the Rio Earth Summit Declaration on Environment and Development namely: 'Human beings are at the centre of concerns for sustainable development. They are entitled to a healthy and productive life in harmony with nature'. Compounding this reality is the lack of central and hierarchical lawmakers akin to the legislature of municipal laws of nation states that could guide the international system. Authoritative sources of International Law and its mechanism of legal charge and reconciliation are weak. Centralized and hierarchical judicial institutions are generally lacking and when there are they are inadequate (Shaw, 1998: 3) to resolve the resulting legal uncertainty in 'a peaceful universe in an age of uncertainty' (The Nation, Lagos, 26 September, 2013). This is because its norms are imprecise, contestable, internally contradictory, overlapping and subject to multiple interpretations and claims [5].

Within the same international system, it has been observed that there are two major arbitrary systems that are vying for control of the world. These are the soft totalitarianism of secularism and the hard totalitarianism of Islam. Secularism has no God and therefore no ultimate standard of value judgement. Every value is relative (ideology of relativism). The result is that each person becomes his own god and does his own thing even if that 'thing' involves the killing of the other person. Islam, on the other hand, does believe in Allah, but not the God Judeo-Christian religious tradition and African Traditional Religion worship. Its faith goes beyond religion; it includes totalitarialism ideology of the type of communism. Until it sheds off its cloak of ideology it ceases to be an authentic religion and remains only as a mere secular system [6].

The two arbitrary systems are really forms of modern slavery. Adherents to Islam may be considered as slaves of a god that does not show compassion, love and mercy to those who do not worship it. The god of this arbitrary system does not promote the rights of others that belong to other faiths while 'secular person' becomes the slave of his own desires and addictions. Therefore, there is an urgent necessity to rediscover anew the Judeo-Christian belief that God is a God of love, justice, reason, goodness and he is the creator of all things and that human beings are made in his image and likeness (a concept which does not exist in Islam). In the context of that vision belief in human dignity and the rights of human is thoroughly justified. People who really believe that they and their neighbours are made in the image of God will generally have a strong sense of their responsibility to act morally (Matt 25: 31-46). This is unlike a belief that killing other person of another faith in the name of religion is a passport to heaven.

Those two arbitrary systems of secularism and the hard totalitarianism of Islam must be confronted headlong. In addition, it must be emphasised that patriarchal and hierarchical structures of dominant religions in the world need to be moulded to accommodate democratic principles in dealing with their adherents and promoting visibility of women as well as youth in their decision-making platforms. In the midst of worldwide terror, destruction, killing, rape and Islamic subtle and sophisticated strategy of expansionism backed by economic buoyancy, the West can no longer be fooled that Islam is a religion of peace as it claims. Except Islam is radically confronted all decent values of peace, freedom, democratic human rights principles of the west and other cultures and religions are heading for extinction by force [7].

The way forward for all stakeholders of the international system in respect of sustainable development is firstly to affirm that the planet earth is a common heritage for all global citizens and whatever catastrophic event that happens to it will correspondently affect not only humanity but all its constituent parts. Therefore, international community can no longer indulge in the game of passing blame by one party to another for the climate change and environmental degradation. Rather the international community should unanimously address credibly and creatively the challenges of symbiotic relationships of national interest ideology, issue of putting human beings at the heart of political and socio-economic activities of global world and the project of low carbon society within the context of international law. Similarly, reform of United Nations Security Council needs to be taken seriously as former President Good Luck Jonathan timely called for at the $68^{\text {th }}$ UN General Assembly of September 2013 [8]. 
Mr. President, I believe that I express the concern of many about the slow pace of effort and apparent lack of progress in the reform of the United Nations, especially the Security Council. We believe strongly, that the call for democratization worldwide should not be for States only, but also, for International Organizations such as the UN. That is why we call for the democratization of the Security Council.

This is desirable for the enthronement of justice, equity, and fairness; and also for the promotion of a sense of inclusiveness and balance in our world' (The Nation, Lagos, September 26 , 2013: 64).

In addition, it may be affirmed that every citizen must embrace attitudinal change towards the common good of the planet given to humanity. Without good governance locally and globally this may not be promoted.

A starting point may begin with environmental education which starts with a critique of the 'myths' of the contemporary world grounded in a utilitarian mindset of individualism, unlimited progress, competition, consumerism, the unregulated market to the advantage of the poor countries, 'we' as opposed to 'them' and technology without ethics.

Educators must develop an ethics of ecology and help people through effective pedagogy to grow in solidarity, responsibility and compassionate care (Pope Francis, 2015: 11 par. 210). The North has to scale down its consumption life style and undertake a critic of technology as a part of the programme. A derogatory use of language to describe the 'others' different from 'us' must be condemned. The words of the formal Zimbabwe President Robert Mugabe must be taken seriously as he hyperbolically stated that

Racism will never end as long as white cars are still using black tyres. Racism will never end if people still use black to symbolize bad luck and white for peace. Racism will never end if people still wear white clothes to weddings and black clothes to funerals. Racism will never end as long as those who don't pay their bills are blacklisted not whitelisted. Even when playing snooker,You haven't won until you've sunk the black ball, and the white ball must remain on the table. But I don't care, as long as I'm still using white toilet paper to wipe my black butt, I'm fine.

\section{President Robert Mugabe is not alone about racism.}

In the context of the West it is just when the world thought, the idea of racism like every other inhuman ideas like slavery are now discussed only in historical terms; certain ideas of racism in their new form (neo-racism) still find their place in our world today. The world had fought and destroyed that system of laws that institutionalized racism, just like the Jim Crow legal racial segregation in America that accepted and enforced the way of thinking and interacting with black people. With that system of laws gone, many social dimensions on life of countries in the west American life began to change. Change that became so swift, and dramatic, that it was surprising that a nation so neo-diverse emerged.
That neo-diversity of everyday lives has made some countries especially countries in the west nervous and sceptical about their everyday walk through life. That anxiety is so strong that it has made many countries in the west to be unnerved. The anxiety in various forms of selective migration rules, xenophobia, and various other prejudices on migration laws and policies are common place.

As a result, it can be concluded that all these events show that the Western world is going through turbulent times, and multiculturalism is in crisis. Neo-racism is threatening the liberal values that the West is proud to possess. The western countries especially America is now witnessing the rise of white supremacist 'extremism' in the heartlands of the birthplaces of democracy and liberalism (the west). The main danger here is that with these events becoming more common, it is very unfortunate that racism, chauvinism, ultra-nationalism and xenophobia are becoming 'ordinary'.

By way of recommendation the following agenda may be unbacked upon by the global community. These are

I. Removal of discrimination of racism, tribalism and gender inequality from the body polity of nation states

II. Equitable power sharing at all levels of governance of nation states;

III. Interrogation of non-harming principle of ontology and property regime in the industrial process milieu

IV. Adherence to sustainable development paradigm.

V. Examination of the ethics of Free Trade from the perspective of safe environment.

VI. Examination of the Timber Trade and its effect on Tropical Forest and the eco-system.

VII. Net working of a powerful and functional civil society as watchdog to challenge global politics.

VIII. A critically discourse on COVID - 19 and Global Health Care.

\section{References}

1. Sands P (1995) Principle of International Environmental Law, Manchester University Press, Manchester. Link: https://bit.ly/2FRBeAO

2. Sands P (1995) International Law in the Field of Sustainable Development In Lang, W. (Ed) Emerging Legal Principles in Sustainable Development and International Law, Graham \&Trotman Publishers. Link: https://bit.ly/3hRkLdh

3. Decleries M (2000) The Law of Sustainable Development: General Principles. A Report produced for the European Commission, Luxembourg: European Communities. Paragraph 6 of Nigeria's National Policy on the Environment 1989 recognises the legal framework as an integral part of the Policy aimed at consolidating, strengthening, providing and extending legislation for environmental protection and improvement in all spheres. The Policy makes it a constitutional duty of governments- Federal, States and Local - to safeguard the environment and aspire to have a healthy nation. Link: https://bit.ly/32Ra3PM

4. Oyeshola D (2019) Sustainable Development: Issues and Challenges for Nigeria ( $2^{\text {nd }}$ Ed), Atman, Osogbo. 
5. Costanza R, McGlade J, Lovins H, Kubiszewski I (2014) An Overarching Goal for the UN Sustainable Development Goals. Solutions 5: 13-16. Link: https://bit.ly/3cm03z9

6. Ignacimuthu (2010) Environmental Spirituality St Pauls, Bandra, Mumbal.
7. McArthur J (2014) 'The Origins of the Millennium Development Goals. SAIS Review XXXIV. Link: https://bit.ly/32R9Ax0

8. Trzyna TC (1995) A Sustainable World: Defining and Measuring Sustainable Development. Sacramento: International Center for the Environment and Policy, California Institute of Public Affairs. Link: https://bit.ly/3iSvVzD

\section{Discover a bigger Impact and Visibility of your article publication with}

\section{Peertechz Publications}

\section{Highlights}

* Signatory publisher of ORCID

* Signatory Publisher of DORA (San Francisco Declaration on Research Assessment)

* Articles archived in worlds' renowned service providers such as Portico, CNKI, AGRIS, TDNet, Base (Bielefeld University Library), CrossRef, Scilit, J-Gate etc.

* Journals indexed in ICMJE, SHERPA/ROMEO, Google Scholar etc.

* OAI-PMH (Open Archives Initiative Protocol for Metadata Harvesting)

* Dedicated Editorial Board for every journal

* Accurate and rapid peer-review process

* Increased citations of published articles through promotions

* Reduced timeline for article publication

Submit your articles and experience a new surge in publication services (https://www.peertechz.com/submission).

Peertechz journals wishes everlasting success in your every endeavours.

Copyright: ๑ 2020 Oyeshola D. This is an open-access article distributed under the terms of the Creative Commons Attribution License, which permits unrestricted use distribution, and reproduction in any medium, provided the original author and source are credited.

Citation: Oyeshola D (2020) Despite various initiatives thus far can there be sustainable development for humanity? Glob J Ecol 5(1): 052-057. 